Agata Hasso-Agopsowicz, Maria Jeleńska, Bogumił Wicik

\title{
MAGNETIC SUSCEPTIBILITY OF CHERNOZEMS
}

\begin{abstract}
Among other forms, iron contained in soil is a component of magnetic minerals, both primary and secondary ones, produced by various soil forming processes. The composition of the soil magnetic fraction, characterised by a magnetic susceptibility, is the consequence of its origin. The character of susceptibility changes along the analysed chernozems' profiles indicates a similarity of the parent rock, as well as the pedogenic processes forming the chernozems from the territories of Poland and the Ukraine. The influence of anthropogenic factors could be seen in the increased susceptibility within the humus horizon of the degraded chernozem.
\end{abstract}

Keywords: soil magnetism, chernozems.

\section{INTRODUCTION}

The ability of matter to get magnetised in the external magnetic field, including the Earth's field, is called a magnetic susceptibility. The studies of magnetic susceptibility measured in small fields, supported by the analysis of other magnetic and/or chemical properties, may be used in the soil diagnosis for determination of its origin (Alexeyev, 1988; Babanin, 1995), and identification of the soil forming processes and factors (Maher, 1986), including anthropogenic ones (Strzyszcz, 1996).

The magnetic susceptibility measurements affect neither the structure nor the chemical composition of the analysed samples, so the results make up a good comparative material for the study of soils developed on the uniform parent rocks. This applies particularly to the numerous genetic subtypes developed on loess in the steppe area. In Polish climatic conditions, chernozems are considered to be relic soils, whose origins (forest-steppe, forestmeadow, man-made?) has not been unambiguously determined. The study of magnetic properties can be helpful in establishing their origins as well as the ways and extent of degradation.

\section{THE MATERIAL AND METHODS OF STUDY}

The analyses were carried out within three soil profiles:

- MD - the non-degraded chernozem from Młodzawy in southern Poland: soil profile taken from a long-term fallowed land, shallow (thickness 
of the humus horizon A of roughly $40 \mathrm{~cm}$ ), loess contains calcium carbonate below the depth of $70 \mathrm{~cm}$;

- K10 - the degraded chernozem from the outskirts of Nowa Huta, southern Poland; cultivated soil, down to the depth of $150 \mathrm{~cm}$ loess displays the granular composition of loamy dust; calcium carbonate below the depth of $150 \mathrm{~cm}$;

- H1 - the ordinary chernozem from the Reserve "Homutovsky Steppe" in the south-eastern Ukraine: the vegetation of the esparto-fescue steppe, soil featuring the granularity of the loamy dust; calcium carbonates observed down from the depth of $40 \mathrm{~cm}$.

The samples were collected within every $10 \mathrm{~cm}$ layer. For all samples the mass specific magnetic susceptibility $(\chi)$ was measured in a small magnetic field.

For selected samples of the air dried soil the following measurements were carried out:

- loss of mass by roasting at temperature of $550^{\circ} \mathrm{C}$, determined with the weight method,

- $\mathrm{pH}$ in $\mathrm{KCl}$ solution - electrometric method,

- organic carbon content $\left(\mathrm{C}_{\mathrm{org}}\right)$ - with Turin's method (oxygenation with potassium bi-chrome),

- iron content $\left(\mathrm{Fe}_{2} \mathrm{O}_{3}\right)$ - iodometric titration of the samples previously roasted and boiled in $10 \% \mathrm{HCl}$.

\section{RESULTS AND DISCUSSION}

\section{CHEMICAL PROPERTIES}

In analysed chernozems, the humus is of mollic type, rich in humin acids. Its highest content, $3.8 \%-5.7 \%\left(2.2-3.3 \mathrm{C}_{\text {org }}\right)$, is observed in the surface soil, strongly overgrown with grass roots or cultivated (Table 1).

In Polish chernozems the humus is observed down to the depth of $70-$ $90 \mathrm{~cm}$. The subsurface horizons (AC) constitute about one third of humus measured in the surface humus horizons (A). In the ordinary chernozem, the A horizon contains more than six times as much organic matter as the $\mathrm{AC}$ horizon, and there is still considerable amount of humus (ca. 0.8\%) at the depth of $180 \mathrm{~cm}$, filling the numerous corridors, primarily the earthworms' one.

The ordinary and the non-degraded chernozems are neutral in reaction ( $\mathrm{pH}$ 6.5-7.2) in the upper parts of the profiles, and become alkaline with depth ( $\mathrm{pH} 7.6-7.7$ in loess). The degraded chernozem is weakly acid down to the depth of $80 \mathrm{~cm}(\mathrm{pH} 6.0-6.4)$.

The iron content reveals a connection with the grain-size distribution of soils. The genetic horizons with the graining of loamy dusts, composing the ordinary chernozem $\mathrm{H} 1$ and the carbonate-free part of the degraded cherno- 
zem K10, are rich in iron (Table 1). The small range of iron content, between $3.83 \%$ and $4.83 \%$, is observed in the $\mathrm{H} 1$ profile. The loess material, with the graining of ordinary dust, present in the shallow non-degraded chernozem MD, as well as in the parent rock horizon (C) of the K10 profile, contain only $2.0-2.5 \%$ of iron. The humus horizons of the MD and H1 profiles show only the slightly increased iron content, in comparison to the non-weathered loess. In the degraded chernozem, the soil weathering processes is marked with the iron content in all the horizons to the depth of $140 \mathrm{~cm}$ almost two times higher than in the parent rock.

\section{MAGNETIC SUSCEPTIBILITY}

In studied profiles, the highest values of magnetic susceptibility are observed in the surface humus horizons, affected by the intensive biochemical processes, while the lowest - in the carbonated loess horizon, consisting of the parent rock (Table 1). Vertical differentiation of the susceptibility, in spite of the iron content is relatively stable within profiles, is related to the various magnetic minerals contribution. The strongly magnetic fraction in the humus horizon is composed mostly of the magnetite or its oxygenated counterpart maghemite, as well as pyrrhotite. In the parent rock, the hematite and goethite is mainly observed.

In the MD profile (the non-degraded chernozem), the susceptibility decrees from $34.55 \cdot 10^{-8} \mathrm{~m}^{3} / \mathrm{kg}$ in the Ap horizon to $14.4 \cdot 10^{-8} \mathrm{~m}^{3} / \mathrm{kg}$ below the depth of $80 \mathrm{~cm}$, corresponding to the parent loess. Such a distribution of susceptibility along the profile is characteristic for the naturally developed chernozems (Babanin, 1995), with the difference that the susceptibility of the ordinary chernozem $\mathrm{H} 1$ is higher along the entire profile, and achieve $81.64 \cdot 10^{-8} \mathrm{~m}^{3} / \mathrm{kg}$ in the A horizon and $30.12 \cdot 10^{-8} \mathrm{~m}^{3} / \mathrm{kg}$ in the loess. This difference can be explained by the higher content of both iron and the organic matter in the $\mathrm{H} 1$ profile. In the degraded chernozem K10 the susceptibility reaches $106.5 \cdot 10^{-8} \mathrm{~m}^{3} / \mathrm{kg}$ at the surface and decreases to $14.47 \cdot 10^{-8} \mathrm{~m}^{3} / \mathrm{kg}$ at the depth of $165 \mathrm{~cm}$.

In the $\mathrm{H} 1, \mathrm{MD}$ and $\mathrm{K} 10$ profiles, from the depth of $40 \mathrm{~cm}$ down, the susceptibility is directly proportional to the organic carbon content, regardless of the chernozem type. The samples from the surface of the K10 profile show a strong susceptibility enhancement, not related to the organic matter content. This points to the anthropogenic source of the magnetic fraction. Since the increased susceptibility is observed in the cultivated layer of this profile, it can be the effect of industrial imission, in view of the nearby steel plants, as well as the agricultural activity, e.g., the use of mineral fertilisers, particularly those containing ashes, or burning the vegetation.

In order to obtain a more complete view on the association of magnetic susceptibility and iron content, more samples of the "pure" loess material are required. The samples of the carbonated loess, representing the parent rock in Polish chernozems, display the same susceptibility, despite the various iron content $(2.0-2.5 \%)$ - see Table 1 . The susceptibility dependence upon 
Selected properties of chernozems

Table 1.

\begin{tabular}{|c|c|c|c|c|c|c|c|}
\hline $\begin{array}{l}\text { Genetic } \\
\text { horizon }\end{array}$ & $\begin{array}{c}\text { Depth } \\
{[\mathrm{cm}]}\end{array}$ & $\begin{array}{l}\text { Loss by } \\
\text { roasting } \\
{[\% \text { dry }} \\
\text { matter] }\end{array}$ & $\mathrm{pH}_{\mathrm{KCl}}$ & $\begin{array}{c}\mathrm{C}_{\mathrm{org}} \\
{[\% \text { dry }} \\
\text { matter }]\end{array}$ & $\begin{array}{c}\mathrm{Fe}_{2} \mathrm{O}_{3} \\
{[\% \text { dry }} \\
\text { matter] }\end{array}$ & $\begin{array}{c}\chi^{*} \\
{\left[10^{-8}\right.} \\
\left.\mathrm{m}^{3} / \mathrm{kg}\right]\end{array}$ & $\chi / \chi_{\mathrm{C}}$ \\
\hline \multicolumn{8}{|c|}{ MD profile - Młodzawy; non-degraded chernozem (fallow land) } \\
\hline Ap & $0-10$ & 8.6 & 7.0 & 2.18 & 2.87 & 34.55 & 2.4 \\
\hline $\mathrm{A}$ & $20-30$ & 4.0 & 7.2 & 1.17 & 2.73 & 36.98 & 2.6 \\
\hline $\mathrm{AC}$ & $50-60$ & 3.5 & 7.4 & 0.72 & 2.51 & 30.68 & 2.1 \\
\hline $\mathrm{C}_{\mathrm{Ca}}$ & $80-90$ & 2.6 & 7.7 & 0.04 & 2.27 & 14.40 & 1.0 \\
\hline $\mathrm{C}_{\mathrm{Ca}}$ & $135-140$ & 2.2 & 7.7 & 0.03 & 2.47 & 14.41 & 1.0 \\
\hline \multicolumn{8}{|c|}{ K10 profile - Nowa Huta; degraded chernozem (arable land) } \\
\hline Ap & $0-10$ & 5.0 & 6.4 & 2.78 & 3.82 & 106.50 & 7.4 \\
\hline A & $40-50$ & 3.4 & 6.2 & 2.09 & 3.13 & 39.59 & 2.7 \\
\hline $\mathrm{AB}_{\mathrm{br}}$ & $60-70$ & 4.0 & 6.0 & 0.88 & 3.99 & 30.41 & 2.1 \\
\hline $\mathrm{B}_{\mathrm{br}}$ & $130-140$ & 2.3 & 7.0 & 0.09 & 3.30 & 19.23 & 1.3 \\
\hline $\mathrm{C}_{\mathrm{Ca}}$ & $165-170$ & 2.4 & 7.3 & 0.05 & 2.01 & 14.47 & 1.0 \\
\hline \multicolumn{8}{|c|}{ H1 profile - "Homutovsky Steppe" Reserve, Ukraine; ordinary chernozem (steppe) } \\
\hline $\mathrm{A}$ & $0-10$ & 12.1 & 6.5 & 3.27 & 4.23 & 81.64 & 2.7 \\
\hline $\mathrm{A}$ & $20-30$ & 10.7 & 6.5 & 2.42 & 4.83 & 83.75 & 2.8 \\
\hline $\mathrm{A}_{\mathrm{Ca}}$ & $50-60$ & 8.6 & 7.4 & 1.51 & 4.43 & 67.95 & 2.3 \\
\hline $\mathrm{AC}_{\mathrm{Ca}}$ & $80-90$ & 7.0 & 7.6 & 0.50 & 3.83 & 28.08 & 0.9 \\
\hline $\mathrm{AC}_{\mathrm{Ca}}$ & $120-130$ & 6.6 & 7.6 & 0.38 & 4.03 & 23.28 & 0.8 \\
\hline$f$ & $180-190$ & 6.9 & 7.6 & 0.47 & 4.23 & 30.12 & 1.0 \\
\hline
\end{tabular}

* The values of $\chi$ for the H1 profile published in Jeleńska et al., 2004.

the iron content is, on the other hand, quite distinct in samples without calcium carbonate, but containing humus.

\section{CONCLUSIONS}

- The vertical magnetic susceptibility distribution, observed in the naturally developed ordinary (Ukraine) and non-degraded (Poland) chernozem profiles, situated nowadays in different vegetation and climatic zones, demonstrates a similar composition of the magnetic fraction, and thus indicates the likeness of the primary material and the pedogenic processes accompanying the development of these soils.

- The susceptibility enhancement in the surface and subsurface horizons by the factor of $2.0-2.8$ in relation to the parent rock was observed in the non-degraded chernozem profiles for various organic matter and iron contents. In natural conditions these chernozems display similar level of enrichment in ferrimagnetic fraction, resulting from the decay 
of the organic matter (Vadyunina, 1972; Mullins, 1977), and limited by its ability to develop the humification process.

- In the ordinary, non-degraded and degraded chernozem profiles below the depth of $40 \mathrm{~cm}$, there is a high correlation between the magnetic susceptibility and the organic matter content. A significant increase of susceptibility in the cultivated layer of the degraded chernozem demonstrates an influence of anthropogenic factors, such as burning vegetation, use of fertilisers containing ash or imission of industrial pollutants.

\section{REFERENCES}

Alexeev A.O., Kovalevskaya J.S., Morgun E.G., Somoylova E.M., 1989, Magnitnaya vosprimchivost' pochv sopriazhennykh landshaftov (Magnetic susceptibility of the soils of associated landscapes; in Russian), Pochvovedeniye, 8, 27-36.

Babanin V.F., Trukhin V.J., Karpatchevskii L.O., Ivanov A.V., Morozov V.V., 1995, Soil Magnetism, Yaroslavl State University Press, Moskva.

Jeleńska M., Hasso-Agopsowicz A., Kopcewicz B., Sukhorada A., Tyamina K., Kąziałko-Hofmokl M., Matviishina Z., 2004, Magnetic properties of the profiles of polluted and non-polluted soils. A case study from Ukraine, Geophys. J. Int., 2004, 159, 104-116.

Maher B.A., 1986, Characterization of soils by mineral magnetic measurements, Physics of the Planetary Interiors, 42, 76-92, Elsevier Science Publishers B.V., Amsterdam.

Mullins C.E., 1977, Magnetic susceptibility of the soil and its significance in soil science: a review, J. Soil Sci., 28, 223-246.

Strzyszcz Z., Magiera T., Heller F., 1996, The influence of industrial emission on the magnetic susceptibility of soils in Upper Silesia, Studia Geophysica et Geodetica 40, $276-286$.

Thompson R. and Oldfield F., 1986, Environmental Magnetism, Allen and Unwin, Winchester, Mass.

Vadyunina A.F., Babanin V.F., 1972, Magnitnaya vosprimchivost' niekotorykh pochv SSSR [Magnetic susceptibility of selected soils of the Soviet Union; in Russian], Pochvovedeniye, $10,55-67$.

Translated by the authors 